\title{
EXTERNAL SOURCES OF FUND OF MICROFINANCE INSTITUTIONS (MFI) IN BANGLADESH: DO INSTITUTIONAL CHARACTERISTICS MATTER?
}

\author{
Serajul Islam \\ Associate Professor \\ Department of Business Administration \\ International Islamic University Chittagong, Chittagong, Bangladesh \\ E-mail: serajulislamiiuc@gmail.com
}

\begin{abstract}
The external sources of fund for the micro-finance institutions (MFIs) include various loans and donor's fund. The loan financing consists of loan from the government, the loan from other micro credit financial institutions, the loan from the commercial bank and the loan from Palli Karma Sahayak Foundation $(P K S F)$. There is the impact of capital resources on the profitability performance. Therefore, it is important for a firm to know about the significant influences of institutional characteristics on external sources of fund. Hence, this study investigates the driven factors of the sources of funds of microfinance institutions, the effect of institutional characteristics on sources of fund especially on external sources. The study is conducted by examining longitudinal data of 169 microfinance institutions (MFIs) from Bangladesh covering a period of six years from 2009 to 2014. This study employs relevant data from the Mix market and Microcredit Regulatory Authority (MRA) annual reports. Results show that a reliance on external sources of the fund (ESF) has a significant correlation with interest rate cap, inflation rate, ROA, number of branches (Size) and age of the MFIs. Donations have a significant correlation with the regularity variable and size of the MFIs. Additionally, apart from location, the rest of the institutional variables significantly influence the external sources of funds (ESF).
\end{abstract}

Keywords: Micro Finance Institution, External Sources of Fund, Capital Structure, and Profitability, Institutional Characteristics, Regularity, Macroeconomic Factor.

JEL Classification Codes: G2, G21, G23, O16.

\section{INTRODUCTION}

The sources of funds for MFI play a vital role on their overall performance. The microfinance industry in Bangladesh optimally utilizes the sources of funds (Mia \& Rana, 2018).Costs of funds depend on the sources of funds, and the fund's sources affect the rate of interest of MFIs (Al-Azzam \& Mimouni, 2016; Assefa \& Meesters, 2013; Cotler \& Almazan, 2013; Dorfleitner \& Mosch, 2013; Fernando, 2006; Ghosh, 2013, Heinen \& Baquero, 2013; Janda \& Zetek, 2018; Roberts, 2013). Policymakers and academicians have been considering interest rates as a major issue in microfinance since its inception (Fernando, 2006, Mersland \& Khafagy, 2013; Rosenberg et al., 2013). If MFI uses external debt (commercial bank's debt) as the source of funds, it increases the cost of funds and increases the interest rate. And it could detain MFI's outreach goal, and clients face financial trouble (Sun \& Im, 2015). Cull and Morduch (2007) considered MFIs as micro banks that aim to gain profitability and poverty alleviation. For promoting these targets, fund's external sources should be used by MFIs (Tchuigoua, 2015). However, it has a small research work regarding the effect of institutional characteristics on sources of funds in MFIs. Therefore, empirically testing the issues driving the fund sources is the 
principal focus of this study. So, answering two questions is the attempt of this study. First, what are the influential factors of the capital structure of MFIs? Second, do institutional characteristics matter on sources of the fund? Institutional characteristics influence the sources of funds of large organizations (Frank \& Goyal, 2009; Rajan \& Zingales, 1995), SMEs (Degryse et al., 2012), and little business (Aktas et al., 2011). But do institutional characteristics matter in the financing choice of MFIs?

There is very limited empirical literature on sources of funds in MFIs. For instance, the effects of institutional life cycle and maturity on financing choice to the MFIs have been identified (De SousaShields \& Frankiewicz, 2004; Ledgerwood \& White, 2006).It has a study on factors influencing funding from abroad for the MFIs. The study found two determinants like return and good outreach, have a positive relationship with international commercial borrowing (Mersland \& Urgeghe, 2013).

Hence, there is a research gap investigating the factors influencing MFI's fund choices in Bangladesh. The study's main findings reveal that regularity variable, macroeconomic variable and institutional characteristics influence the external sources of funds of MFIs in Bangladesh.

This study will help policymakers and managers minimize the cost of funds and get sufficient funding from both the debt and equity sources. The rest of the study's sections are conceptual framework, research methodology, results and findings and concluding remarks.

\section{LITERATURE REVIEW}

In the present day, the increasing number of microfinance NGOs are focusing more on the deposit collections than giving credit for providing saving service to low-income people. So, they increase their capacity to mobilize and intermediate voluntary savings (Ledgerwood \& White, 2006). But most of the MFIs are trying to eradicate poverty by giving a loan to poor people mostly based on subsidies (Morduch, 1999).

Client savings is one of the sources of fund of MFIs. Microfinance is a growing flexible means of widening access to financial services to alleviate poverty (Armendariz de Aghion \& Morduch, 2010). Accessing medium to long term sustainable commercial sources of the fund is one of the major challenges of MFIs. The sources of funds of MFIs are shareholders fund, customer's deposit, debenture, qualifying medium to long-term loans, grants or donations from individuals, organizations, government and international sources (Anyanwu, 2004).

Hasan and Ahmed (2009) said that members' savings, commercial banks and the stock market are the future sources of MFIs. According to his study, there is a lack of efficiency in the system of mobilizing funds to MFIs. It is very difficult to give figures on how much donor funds go to the poor. Donor funds are mainly allocated for administrative uses, and only a few percent is spent on the poor (Yunus, 1999).

Hartarska and Nadolnyak (2008) found the negative relationship between the leverage of MFIs and their sustainability. Currently, the source of funds of MFIs is a vital issue in finance though there are several barriers to raising capital, which hamper the growth of MFIs (Bogan, 2012). Hartarska and Nadolnyak (2008) mentioned that all the rating agencies do not influence MFIs' funds' sources. But the commercial investment is necessary to fund the continued expansion of microfinance (Cull, DemirgucKunt, \& Morduch, 2009).

Garmaise and Natividad (2010) mentioned two reasons for differing financing sources of MFIs from banks. First, the demand deposit is not the main source of finance. Second, noncommercial lenders provide the debt financing of MFIs. Adongo and Stork (2006) found that a positive relationship between donor involvement in providing start-up funds for the loan portfolio and financial sustainability.

The cost of funds is an important issue for all MFIs in Bangladesh. For example, Rosenberg, Gonzalez, and Narian (2009) found that cost of funds is one of the four influencing factors of interest rates in MFIs. They also found that most of the total cost is operating depending on organizational features like the age of the MFI, location and loan size etc. Also, Jayadev and Rao (2012) opined that funds' cost is the most influencing element for fixing the MFIs' interest rate. They also mentioned that MFIs are less leveraged than commercial banks. 
Sources of funds are debt and equity. The unique nature of MFI's sources of the fund is the sponsored external financing (Tchuigoua, 2015). A lot of MFIs still use subsidized funds as their sources of capital (Armendariz de Aghion \& Morduch, 2010). The sources of fund composition of MFIs in Bangladesh are the client's savings, the government's loan, loans from other MFIs, the loan from commercial banks, other loans, cumulative surplus, other funds, and the loan PKSF, and donor's fund.

\section{METHODOLOGY}

The methodology part includes modeling the determinants of funds and data sources.

\section{Modeling Determinants of Sources of Funds}

Janda and Zetek (2018) used both the factors (internal \& external) to develop an econometric model. For deriving such a model, the same method has been followed here. Therefore, the model can be expressed as follows:

$$
E S F_{i t}=\alpha 0+\beta_{1} \ln \mathrm{NOB}_{\mathrm{it}}+\beta_{2} \mathrm{ROA}_{\mathrm{it}}+\beta_{3} \mathrm{LOC}_{\mathrm{it}}+\beta_{4} \ln \mathrm{AGE}_{\mathrm{it}}+\beta_{5}\left(\ln \mathrm{AGE}_{\mathrm{it}}\right)^{2}+\mathrm{ZX}_{\mathrm{it}}+\varepsilon_{\mathrm{it}}
$$

Here 'i' stands for the microfinance institutions with a time, ' $t$ ' and $€$ it expresses the stochastic error. The dependent variable, external sources of the fund (ESF), has been used as a proxy to capture all the major external sources. The major external sources of funds are a loan from the government (GOVT), the loan from other MFI (MFIB), the loan from the commercial bank (BANK), the loan from PKSF (PKSF), and donors' fund (DON). The exclusive dependent variables are only CSAV and CUMS two internal sources of funds.

The model includes the size of MFI that is represented by the number of branches (B), profitability measured by return on assets (ROA), location (LOC), and age of MFI (AGE). Hence, the model focuses on five institutional characteristics. Generally, there is a positive relationship between profitability and debt financing. So, ROA affects sources of funds. Location is included to examine what location chooses what type of financing more. The number of branches, i.e., the size of MFI, also affects capital structure. Normally, it has a positive relation with external financing. Besides, the age (AGE) of MFIs represents the consequence of experience and long life on the financing policy. Usually, the superior the age, the bigger the practice of a microfinance institution. So it has a hands-on experience that may affect the external financing policy. Furthermore, the present study has also included AGE2 to explore the opportunity of a non-linear correlation with external funding policy to confine the 'learning curve' effect (Mia \& Rana, 2018). Also, to overcome simultaneity bias and improve the regression model's goodness of fit, the model transferred AGE and B into natural logarithms (De Bandt \& Davis, 2000).

The model also includes three macroeconomic issues and one regulatory factor. These variables are the control variables to estimate the model (Ahlin, Lin, \& Maio, 2011). Since an interest rate cap is introduced for controlling the rates of interest in micro-financing, the analysis anticipates the negative impact of INTCP on external funding. Moreover, the GDP growth rate reveals the economic condition that may positively relate to the funds' external sources. Another control variable, the inflation (INF) rate of the model to be expected negatively related with the funding from external sources. However, the model's exchange rate (EXC) may positively correlate with the donation and negatively with the capital's remaining external sources. The definitions and measurement units of the variables are given in the table below: 
Table 1. Definitions and measurement units of the variables

\begin{tabular}{|c|c|c|}
\hline Variable & Definition & Unit \\
\hline \multicolumn{3}{|l|}{$\begin{array}{l}\text { External Sources of fund } \\
\text { (ESF): dependent variables }\end{array}$} \\
\hline Government funds (GOVT) & $\begin{array}{l}\text { Amount of government loans (state-owned bank) and } \\
\text { concessionary funds divided by the total amount of } \\
\text { fund of an MFI*100 }\end{array}$ & $\%$ \\
\hline Peer borrowing (MFIB) & $\begin{array}{l}\text { Total amount of borrowed capital from peer MFIs } \\
\text { divided by the total amount of fund of an MFI* } 100\end{array}$ & $\%$ \\
\hline $\begin{array}{l}\text { Loan from commercial bank } \\
\text { (BANK) }\end{array}$ & $\begin{array}{l}\text { Total amount of borrowed capital from commercial } \\
\text { banks divided by the total funds of an MFI*100 }\end{array}$ & $\%$ \\
\hline $\begin{array}{l}\text { Loan from Palli Karma Sahayak } \\
\text { Foundation (PKSF) }\end{array}$ & $\begin{array}{l}\text { Amount of PKSF funds divided by the total funds of } \\
\text { an MFI*100 }\end{array}$ & $\%$ \\
\hline Donors' fund (DON) & $\begin{array}{l}\text { Total amount of donations divided by the total funds } \\
\text { of an MFI*100 }\end{array}$ & $\%$ \\
\hline \multicolumn{3}{|l|}{ Independent Variables } \\
\hline Number of Branches (B) & $\begin{array}{l}\text { Size of an MFI is based on the total number of } \\
\text { branch }\end{array}$ & Number \\
\hline Return on Asset (ROA) & Total earnings divided by total asset & Ratio \\
\hline Location (LOC) & $\begin{array}{l}\text { Dummy variable- } 1 \text {, if the MFI was registered in the } \\
\text { capital city of Dhaka, } 0 \text { otherwise }\end{array}$ & 0,1 \\
\hline Age of MFI (AGE) & Year of establishment (registration) of an MFI & Number \\
\hline Interest rate caps (INTCAP) & $\begin{array}{l}0 \text { before the interest rates cap in } 2011 \text { and } \\
1 \text { after, dummy variable }\end{array}$ & 0,1 \\
\hline GDP growth rate (GDPGR) & Annual Gross Domestic Product growth & $\%$ \\
\hline Inflation (INF) & Rate of price change in the economy as a whole & $\%$ \\
\hline Exchange rate $(\mathrm{EXC})$ & $\begin{array}{l}\text { Exchange rate between Bangladeshi Taka and US } \\
\text { dollar }\end{array}$ & Ratio \\
\hline \multicolumn{3}{|l|}{ Exclusion Variables } \\
\hline Savings (CSAV) & $\begin{array}{l}\text { Amount of savings divided by the total amount of } \\
\text { fund of an MFI*100 }\end{array}$ & $\%$ \\
\hline Cumulative Surplus (CUMS) & $\begin{array}{l}\text { Amount of cumulative surplus divided by the total } \\
\text { amount of fund of an MFI*100 }\end{array}$ & $\%$ \\
\hline
\end{tabular}

\section{Data Sources}

This research used only secondary information, including annual reports of the Microcredit Regulatory Authority (MRA), Bangladesh. This study has included a period of six years, from 2009 to 2014. During this period, those MFIs existed and completed datasets are considered for the study as the number of MFIs is not equal. Accordingly, one hundred sixty-nine samples are finalized for the study.

\section{FINDINGS AND DISCUSSION}

The winsorized observations are used in descriptive statistics and regressions. Descriptive Statistics of the variables are given in the table- 2 . 
Table 2. Descriptive statistics of the variables

\begin{tabular}{|c|c|c|c|c|c|}
\hline Variable & Obs & Mean & Std. Dev. & Min & Max \\
\hline & & & & & \\
\hline INTCAP & 1014.000 & 0.500 & 0.500 & 0.000 & 1.000 \\
\hline INF & 1014.000 & 7.498 & 1.678 & 5.423 & 10.705 \\
\hline EXC & 1014.000 & 78.483 & 8.973 & 65.558 & 86.742 \\
\hline GDPGR & 1014.000 & 5.950 & 0.525 & 5.000 & 6.500 \\
\hline DON & 1011.000 & 2.097 & 7.453 & 0.000 & 43.990 \\
\hline BANK & 1011.000 & 4.627 & 11.082 & 0.000 & 54.130 \\
\hline GOVT & 1011.000 & 1.546 & 4.706 & 0.000 & 28.360 \\
\hline MFIB & 1011.000 & 1.585 & 4.832 & 0.000 & 28.420 \\
\hline PKSF & 1011.000 & 22.610 & 27.618 & 0.000 & 89.540 \\
\hline ROA & 1012.000 & 3.226 & 3.956 & -10.170 & 16.000 \\
\hline AGE & 1014.000 & 16.878 & 7.582 & 4.000 & 38.000 \\
\hline B & 1014.000 & 56.512 & 229.056 & 1.000 & 2029.000 \\
\hline LOC & 1014.000 & 0.290 & 0.454 & 0.000 & 1.000 \\
\hline
\end{tabular}

\section{Source: Authors}

From the descriptive statistics table (table\#2), we find that PKSF is the largest source among all external sources. It has a mean value of $27.62 \%$, whereas its maximum value is $89.54 \%$. The second highest external source of funds is BANK, and its mean value and highest value are $4.63 \%$ and $54.13 \%$, respectively. The other external sources are DON, MFIB and GOVT, and their mean values are 2.1\%, $1.59 \%$ and $1.55 \%$, respectively. It is also found that some of the MFIs only depend on internal sources of funds.

On the contrary, some MFIs depend mostly on external sources because their maximum values are more than $50 \%$. The average growth rate of gross domestic product (GDP) has been found the medium rate of $5.95 \%$ during the sample period.

Table 3. Pair wise correlation

\begin{tabular}{|l|r|r|r|r|r|r|r|r|}
\hline & $\ln B$ & \multicolumn{1}{l}{$\ln A G E$} & INTCAP & INF & EXC & GDPGR & ROA & LOC \\
\hline & & & & & & & & \\
\hline $\ln B$ & 1 & & & & & & & \\
\hline $\ln$ AGE & 0.4086 & 1 & & & & & & \\
\hline INTCAP & 0.024 & 0.2204 & 1 & & & & & \\
\hline INF & 0.0033 & 0.0184 & -0.3496 & 1 & & & & \\
\hline EXC & 0.0203 & 0.1907 & 0.6191 & 0.399 & 1 & & & \\
\hline GDPGR & 0.0186 & 0.1641 & 0.4762 & 0.5176 & 0.901 & 1 & & \\
\hline ROA & 0.079 & 0.0277 & 0.0632 & 0.011 & 0.0576 & 0.06 & 1 & \\
\hline LOC & -0.09 & -0.1619 & 0 & 0.0002 & 0.0003 & -0.0001 & 0.017 & 1 \\
\hline
\end{tabular}

From the pair wise correlation table, it is found that there is multicollinearity between GDPGR and EXC. The correlation of only these independent variables (0.901) exceeds the highest limit of 0.80 (Kennedy, 2008). Therefore, these two variables are not used together in the same model.

The mostly used systems for analyzing panel data are fixed effect (FE) analysis and random effect (RE) analysis (Torres-Reyna, 2007). This study is based on panel data. Hence, random effect 
analysis has been chosen through the Hausman (1978) test, and the discussion is based on the results of $\mathrm{RE}$ analysis. Robust standard errors have been measured in all the models.

Table 4. Determinants of External Sources of Funds (Random effect)

\begin{tabular}{|c|c|c|c|c|c|}
\hline & (1) & (2) & (3) & (4) & $(5)$ \\
\hline & DON & BANK & GOVT & MFIB & PKSF \\
\hline INTCAP & $\begin{array}{c}-1.1901^{* *} \\
(0.4938)\end{array}$ & $\begin{array}{c}4.4997^{* * * *} \\
(0.8566)\end{array}$ & $\begin{array}{c}0.1181 \\
(0.3749)\end{array}$ & $\begin{array}{l}-0.3510 \\
(0.3689)\end{array}$ & $\begin{array}{c}-7.6903^{* * *} \\
(1.3972)\end{array}$ \\
\hline INF & $\begin{array}{c}-0.1981 \\
(0.1282)\end{array}$ & $\begin{array}{l}0.5537^{* *} \\
(0.2381)\end{array}$ & $\begin{array}{c}0.0339 \\
(0.1039)\end{array}$ & $\begin{array}{c}0.0053 \\
(0.1005)\end{array}$ & $\begin{array}{c}-1.0956^{* * * *} \\
(0.3347)\end{array}$ \\
\hline GDPGR & $\begin{array}{c}0.3055 \\
(0.4135)\end{array}$ & $\begin{array}{c}-0.6244 \\
(0.7873)\end{array}$ & $\begin{array}{c}0.0109 \\
(0.3433)\end{array}$ & $\begin{array}{l}-0.4713 \\
(0.3300)\end{array}$ & $\begin{array}{c}1.2231 \\
(1.0408)\end{array}$ \\
\hline ROA & $\begin{array}{l}-0.0117 \\
(0.0359)\end{array}$ & $\begin{array}{c}-0.1568^{* * *} \\
(0.0674)\end{array}$ & $\begin{array}{c}0.0078 \\
(0.0294)\end{array}$ & $\begin{array}{l}-0.0007 \\
(0.0284)\end{array}$ & $\begin{array}{c}-0.2395^{* * * *} \\
(0.0902)\end{array}$ \\
\hline LOC & $\begin{array}{c}-0.5931 \\
(1.1575)\end{array}$ & $\begin{array}{c}0.6692 \\
(1.4999)\end{array}$ & $\begin{array}{l}-0.7194 \\
(0.6659)\end{array}$ & $\begin{array}{c}-0.6076 \\
(0.7148)\end{array}$ & $\begin{array}{l}-2.1209 \\
(4.1738)\end{array}$ \\
\hline $\ln A G E$ & $\begin{array}{c}3.8966 \\
(3.7356)\end{array}$ & $\begin{array}{c}1.9699 \\
(6.5830) \\
\end{array}$ & $\begin{array}{c}12.7062^{* * *} \\
(2.8834)\end{array}$ & $\begin{array}{c}-0.1796 \\
(2.8426) \\
\end{array}$ & $\begin{array}{c}37.5285^{\text {**** }} \\
(9.8969)\end{array}$ \\
\hline $\ln B$ & $\begin{array}{c}0.8014^{* * *} \\
(0.3059)\end{array}$ & $\begin{array}{l}1.5626^{* * * *} \\
(0.4361)\end{array}$ & $\begin{array}{c}-0.2817 \\
(0.1930)\end{array}$ & $\begin{array}{l}-0.3428^{*} \\
(0.2025)\end{array}$ & $\begin{array}{c}2.5350^{* * * *} \\
(0.9515)\end{array}$ \\
\hline $\ln A G E 2$ & $\begin{array}{c}-0.7772 \\
(0.7936)\end{array}$ & $\begin{array}{c}-0.6757 \\
(1.3364)\end{array}$ & $\begin{array}{c}-2.4494^{* * *} \\
(0.5863)\end{array}$ & $\begin{array}{c}0.0216 \\
(0.5846)\end{array}$ & $\begin{array}{l}-5.5776^{* *} \\
(2.2312)\end{array}$ \\
\hline _cons & $\begin{array}{l}-3.9232 \\
(4.8487)\end{array}$ & $\begin{array}{l}-1.5115 \\
(8.7333)\end{array}$ & $\begin{array}{c}-13.8632^{* * * *} \\
(3.8214)\end{array}$ & $\begin{array}{c}5.8148 \\
(3.7444)\end{array}$ & $\begin{array}{c}-36.5324^{* * * *} \\
(12.5414)\end{array}$ \\
\hline$N$ & 1009 & 1009 & 1009 & 1009 & 1009 \\
\hline \multicolumn{6}{|l|}{$\mathrm{F}$} \\
\hline \multicolumn{6}{|l|}{ r2_a } \\
\hline N_g & 169.0000 & 169.0000 & 169.0000 & 169.0000 & 169.0000 \\
\hline
\end{tabular}

Standard errors in parentheses

${ }^{*} p<0.10,{ }^{* *} p<0.05,{ }^{* * *} p<0.01$

Since the fitness on the whole of the guesstimates is rationally fine, the modeling of determinants of external sources of funds (ESF) is robust. Though the data has a different scale of importance, Fstatistics is significant here.

The result of the donation model (model 1) indicates that the regulatory variable, INTCAP, harms the DON, one external source of fund. This result is inconsistent with the findings of a positive relationship between regulation and donation, and the regulatory control administers the activities of MFIs that offer intrinsic assurances (Demirguc-Kunt \& Maksimovic, 1999). But institutional variable $\operatorname{lnB}$ has a positive effect on DON. It suggests that donors pay attention to the size of the MFIs, which is supported by the findings that donors' attention is high on the effective use of their grants and expansion (Tchuigoua, 2015). The result is also supported by the experimental (Buchheit \& Parsons, 2006) and pragmatic study (Tinkelman, 1998; Trussel \& Parsons, 2007). There is no significant impact of macroeconomic variables INF and GDPGR on the DON. Profitability (ROA) does not have a significant effect on DON. The findings are the direct opposite of the literature, which maintains the affirmative signal of financial soundness with donations (Trussel \& Parsons 2007) and two specific institutional characteristics LOC and AGE, do not have any significant influence on DON.

The result of the bank model (model 2) indicates that the regulatory variable, INTCAP has a positive effect on the bank loan, which is an interesting finding because it controls interest rate that 
makes a barrier for external sourcing of funds. This result is inconsistent with the expectation. Additionally, macroeconomic variable INF (inflation) has a positive effect on a bank loan that is opposite to the initial expectation. The most striking finding reveals that inflation positively influences MFIs for borrowing from commercial banks. But another macroeconomic variable, GDPGR, harms bank loans though it loses its statistical significance. ROA has a negative influence on loans from commercial banks. It suggests that MFIs should use retained earnings as the new financing to reduce the dependency on borrowing. The result is supported by the profitability that is negatively associated with borrowings (Tchuigoua, 2015).There is no significant impact on the location and age of the MFIs on debt from commercial banks. However, another institutional variable ( $\mathrm{LnB})$, the size of MFI, positively influences commercial banks' loans. Hence, the size of MFI is a determinant of debt by bank-loan, where the organization is small or has a small number of branches (Almeida \& Campello, 2007).

The result of the GOVT model (model 3) indicates that the regulatory variable, INTCAP, has a positive effect on the loan from the government (GOVT), but it is statistically insignificant. Also, macroeconomic variables INF (inflation) and GDPGR have a positive effect on GOVT that is the opposite of the initial expectation though the variables lose their statistical significance. ROA has a positive influence on government loans, and it is also statistically insignificant. There is no significant impact of location and number of branches of the MFIs on government debt. However, another institutional variable (LnAge), the age of MFI, positively influences the government's loans. Hence, the age of MFI is an important determinant for MFI debt financing from government loans.

The result of the MFIB model (model 4) indicates that the regulatory variable, INTCAP, hurts the loan from other MFI (MFIB), but it is statistically insignificant. Besides, macroeconomic variables INF (inflation) and GDPGR have a statistically insignificant impact on MFIB. Profitability (ROA) negatively influences loans from other microfinance institutions, and it is also statistically insignificant. There is no significant impact of location and age of the MFIs on debt from other MFIB. However, another institutional variable ( $\mathrm{LnB})$, the number of branches of MFI, has a positive influence on loan from other MFIs. Therefore, the size of MFI is an important determinant for MFI debt financing from MFIB.

The result of the PKSF model (model 5) indicates that the regulatory variable, INTCAP harms the PKSF loan, which is very much consistent with the prior expectation because it controls interest rate that makes a barrier for external sourcing of fund. Besides, the macroeconomic variable INF (inflation) also harms the PKSF loan consistent with the initial expectation. But another macroeconomic variable GDPGR has a positive impact on PKSF loan though it loses its statistical significance. ROA has a negative influence on loan from PKSF. This result proposes that MFIs should use equity as the new financing to reduce debt financing dependency. Although the negative relation of ROA with the debt financing is consistent with the previous studies (Hartaska \& Nadolnyak, 2008; Gropp \& Heider, 2010), the role of operating efficiency or profitability on loan from PKSF is significant. There is no significant impact on the location of the MFIs on debt from PKSF. However, other institutional variables (LnAge), age of MFI, and the number of branches ( $\mathrm{LnB}$ ), have positive influences on loan from PKSF. Therefore, age and number of branches of MFIs are the important determinants for MFI debt financing from PKSF loans.

Additionally, the outcome reveals that the size of MFI has a significant association with debt from PKSF. Reputations of big MFIs are higher, and such institutions can manage their risks efficiently. As a result, they are less risky than small MFIs.

\section{CONCLUSION}

This research has contracted with a vital micro-finance issue by recognizing the elements influencing external sources of funds. Some necessary policy propositions for MFIs have been found from the discussion and analysis. GDPGR and LOC have no significant influence on the ESF. So, other significant determinants of ESF are INTCAP, INF, ROA, Size and AGE. Except for LOC, all the institutional characteristics influence the external sources of funds of microfinance institutions (MFIs) significantly, particularly in Bangladesh. In the DON model, findings prove that the regulatory variable 
and size of the MFIs have a significant influence on the donors' fund. It reveals a positive relationship between the number of donations and the size of MFIs, suggesting that large MFIs attract more donations. Also, for the bank and PKSF model, the size of MFI has the likely impact on the loan from the bank and PKSF. However, there is no consistency with the previous study (Tchuigoua, 2015) that states that donors provide higher for sustaining tiny microfinance institutions' growth.

Additionally, it is found from the donation model that an interest rate cap has a negative effect on the donors' decision. The same negative effect of interest rate cap has been found for the PKSF model, and the relationship is also significant between this regulatory intervention and PKSF's fund. However, the interest rate cap has a significant positive role on the bank loan. This finding reveals that the bank is willing to give a loan if there is an interest ceiling for controlling excessive interest rates as it reduces their default risk. One interesting finding is that this intervention policy is ineffective for the fund from the government and other microfinance institutions. The result is supported by the empirical study that there is an ineffectiveness of interest rate cap policy on the portfolio yield of MFIs (Mia \& Rana, 2018).

The macroeconomic factor, inflation, has a significant positive effect on a bank loan and a negative impact on PKSF's fund. Profitability has no significant impact on donations, the government's fund, and the loan from other MFIs supported by Tchuigoua (2015). It claimed that donors do not mainly expect a rate of return. But it has a significant negative impact on loans from commercial banks and PKSF, which is a very interesting finding. The study reveals that commercial lenders are more sensitive to profitability than noncommercial lenders. The finding is inconsistent with the previous study, as mentioned by Matth"aus-Maier and Von Pischke (2006) that commercial banks are making more investments in microfinance not only for charity but also for getting returns. There is a positive relationship between profitability and commercial bank loan (de Mel, McKenzie, \& Woodruff, 2008). The study also found that the government and PKSF encourage small MFIs for their sustainability by giving more funds than the larger MFIs. This negative relation among the age of the MFIs, GOVT and PKSF are statically significant.

Future studies could be done to find the determinants of cross-border funding of microfinance and examine the effect of the lawful organizational and regulatory framework on the capital formation of MIFs in Bangladesh.

\section{REFERENCES}

Ahlin, C., Lin, J., \& Maio, M. (2011). Where Does Microfinance Flourish? Microfinance Institution Performance in Macroeconomic Context. Journal of Development Economics, 95(2), 105-120.

Adongo, J., \& Stork, C. (2006). Factors influencing the financial sustainability of selected microfinance institutions in Namibia (No. 39). Namibian Economic Policy Research Unit.

Aktas, N., Bellettre, I., \& Cousin, J. G. (2011). Capital structure decisions of French very small businesses. Finance, 32(1), 43-73.

Al-Azzam, M., \& Mimouni, K. (2016). Is Exchange Rate Risk Priced in Microfinance? Research in International Business and Finance, 36, 520-531.

Almeida, H., \& Campello, M. (2007). Financial constraints, asset tangibility, and corporate investment. The Review of Financial Studies, 20(5), 1429-1460.

Anyanwu, C. M. (2004, November). Microfinance institutions in Nigeria: policy, practice and potentials. In G24 Workshop on "Constraints to Growth in Sub Saharan Africa," Pretoria, South Africa (pp. 1-31). 
Armendariz de Aghion, B., \& Morduch, J. (2010). The Economics of Microfinance (2nd ed.). Cambridge, MA: MTT Press.

Ahmed, S. (2009). Microfinance institutions in Bangladesh: achievements and challenges. Managerial Finance, 35(12), 999-1010.

Assefa, E. N., \& Meesters, A. (2013). Competition and the Performance of Microfinance Institutions. Applied Financial Economics, 23(9), 767-782.

Bogan, V. L. (2012). Capital structure and sustainability: An empirical study of microfinance institutions. Review of Economics and Statistics, 94(4), 1045-1058.

Buchheit, S., \& Parsons, I. M. (2006). An Experimental Investigation of Accounting Information's Influence on the Individual Giving Process. J Account Public Policy, 25, 666-686.

Cotler, P., \& Almazan, D. (2013). The Lnding Interest Rates in the Microfinance Sector: Searching for its Determinants. Journal of CENTRUM Cathedra: The Business and Economics Research Journal, 6(1), 69-81.

Cull, R., \& Morduch, J. (2007). Financial Performance and Outreach: A Global Analysis of Leading Microbanks. The Economic Journal, 117, F107-F133.

Cull, R., Demirguc-Kunt, A., \& Morduch, J. (2009). Microfinance Meets The Market. J Econ Prospect, 23, 167-192.

De Bandt, O., \& Davis, E. (2000). Competition, Contestability and Market Structure in European Banking Sectors on the Eve of EMU. Journal of Banking and Finance, 24(6), 1045-1066.

de Mel, S., McKenzie, D., \& Woodruff, C. (2008). Returns to Capital in Microenterprises: Evidence from a Field Experiment. Quarterly Journal of Economics, 123, 1329-1372.

De Sousa -Shields., M., \& Frankiewicz., C. (2004). Financing Microfinance Institutions: The Context for Transition to Private Capital. USAID, Washington DC, 174-178.

Degryse., H., de Goeij., P., \& Kappert., P. (2012). The impact of firm and industry characteristics on small firms' capital structure. Small Bus Econ, 38, 431-447.

Demirguc-Kunt, A., \& Maksimovic, V. (1999). Institutions , Financial Markets, and Firm Debt Maturity. J Financ Econ, 54, 295-336.

Dorfleitner, G. M., \& Mosch, J. V. (2013). What Dettermines Microcredit Interest Rates? Applied Financial Economics, 23(20), 1579-1597.

Frank, M. Z., \& Goyal, V. K. (2009). Capital structure decisions: which factors are reliably important?. Financial management, 38(1), 1-37.

Fernando, N. A. (2006). Understanding and Deealing with High Interest Rates on Microcredit. Asian Development Bank, 13, 1-13.

Garmaise, M. J., \& Natividad, G. (2010). Infomation, the Cost of Credit and Operational Efficiency: An Empirical Study of Microfinance. The Society for Financial Studies , 2560-2587. 
Ghosh, J. (2013). Microfinance and the Challenge of Financial Inclusion for Development. Cambridge Journal of Economics, 37, 1203-1219.

Gropp, R., \& Heider, F. (2010). The Determinants of Bank capital Structure. Rev Financ, 14, 587-622.

Hausman, J. A. (1978). Specification Tests in Econometrics. Econometrica : Journal of the Econometric Society, 46, 1251-1271.

Heinen, A. H., \& Baquero, G. (2013). Competition, Loan Rates and Information Dispersion in Microcredit Markets.

Hartarska, V., \& Nadolnyak, D. (2008). Does rating help microfinance institutions raise funds? Crosscountry evidence. International Review of Economics \& Finance, 17(4), 558-571.

Janda, K., \& Zetek., P. (2018). Macroeconomic Factors Influencing Interest Rates of Microfinance Institutions in the Latin America and Caribbean. Agricultural Economics, 60(4), 159-173.

Jayadev, M., \& Rao, R. N. (2012). Financial Resources of the Microfinance Sector: Securitization Deals-Issues and Challenges Interview with the MFIs Grameen Koota and Equitas. IIMB Management Review, 24(1), 28-39.

Kennedy, P. (2008). A Guide To Econometrics (6th ed.). New Jersy: Wiley-Blackwell.

Ledgerwood., J., \& White., V. (2006). Transforming Microfinance Institutions: Providing Full Financial Services To The Poor . World Bank, Washington DC, 205-210.

Matth“aus-Maier, I., \& Pischke, J. V. (2006). Microfinance Investment Funds: Leveraging Private Capital. Berlin: Springer.

Mersland, R., \& Khafagy, A. (2013). Towards Reasonably Priced Microcredit Analysing Egyptian NGO-MFIs' Cost Structure and Financial Performance. Enterprise Development and Microfinance, 24(4), 328-345.

Mersland, R., \& Urgeghe, I. (2013). International Debt Financing and Performance of Microfinance Institutions. Strat Change, 22(1-2), 17-29.

Mia, M. A., \& Rana, M. S. (2018). What affects portfolio yield of microfinance institutions? Evidence from Bangladesh. African Journal of Science, Technology, Innovation and Development, 10(3), 345-353.

Morduch, J. (1999). The Mcrofinance Promise. Journal of Economic Literature, 37, 1569-1614.

Rajan, R. G., \& Zingales, L. (1995). What do we know about capital structure? Some evidence from international data. The journal of Finance, 50(5), 1421-1460.

Roberts, P. W. (2013). The Profit Orientation of Microfinance Institutions and Effective Interest Rates. World Development, 41, 120-131.

Rosenberg, R., Gaul, S., Ford, W., \& Tomilova, O. (2013). Microcredit interest rates and their determinants: 2004-2011. In Microfinance 3.0 (pp. 69-104). Springer, Berlin, Heidelberg. 
Rosenberg, R., Gonzalez, A., \& Narain, S. (2009). The New Moneylenders: Are The Poor Being Exploited by High Microcredit Inteest Rates? In Moving Beyond Storytelling: Emerging Research in Microfinance, 145-181.

Sun, S. L., \& Im, J. (2015). Cutting microfinance interest rates: An opportunity co-creation perspective. Entrepreneurship Theory and Practice, 39(1), 101-128.

Tchuigoua, H. T. (2015). Capital Structure of Microfinance Institutions. Journal of Financial Services Research, 47(3), 313-340.

Tinkelman, D. (1998). Differences in sensitivity of financial statement users to joint cost allocations: The case of nonprofit organizations. Journal of Accounting, Auditing \& Finance, 13(4), 377393.

Torres-Reyna, O. (2007). Panel Data Analysis Fixed and Random Effects Using Stata (V. 4.2).

Trussel, J., \& Parsons, L. (2007). Financial Reporting Factors Affecting Donations to Charitable Organizations. Adv Account, 23, 263-285.

Yunus, M. (1999). The Grameen Bank. Scientific American, 281(5), 114-119.

Appendix: Table A1: OLS for model-1

\section{APPENDICES}

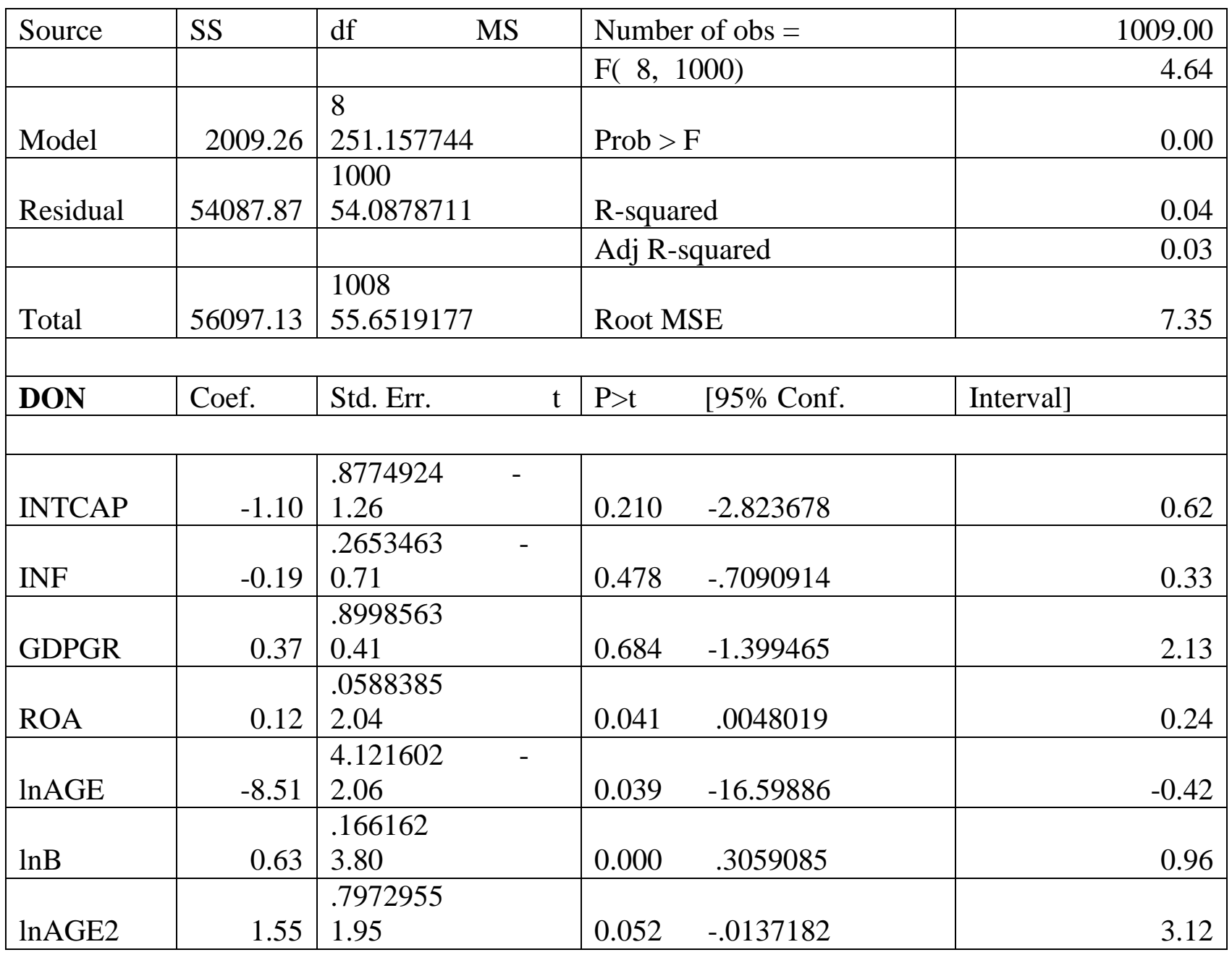




\begin{tabular}{|c|c|c|c|c|c|}
\hline LOC & -0.73 & $\begin{array}{l}.5170545 \\
1.40\end{array}$ & 0.161 & -1.740735 & 0.29 \\
\hline _cons & 11.57 & $\begin{array}{l}6.291318 \\
1.84\end{array}$ & 0.066 & -.779339 & 23.91 \\
\hline
\end{tabular}

Table A2: OLS for model-2

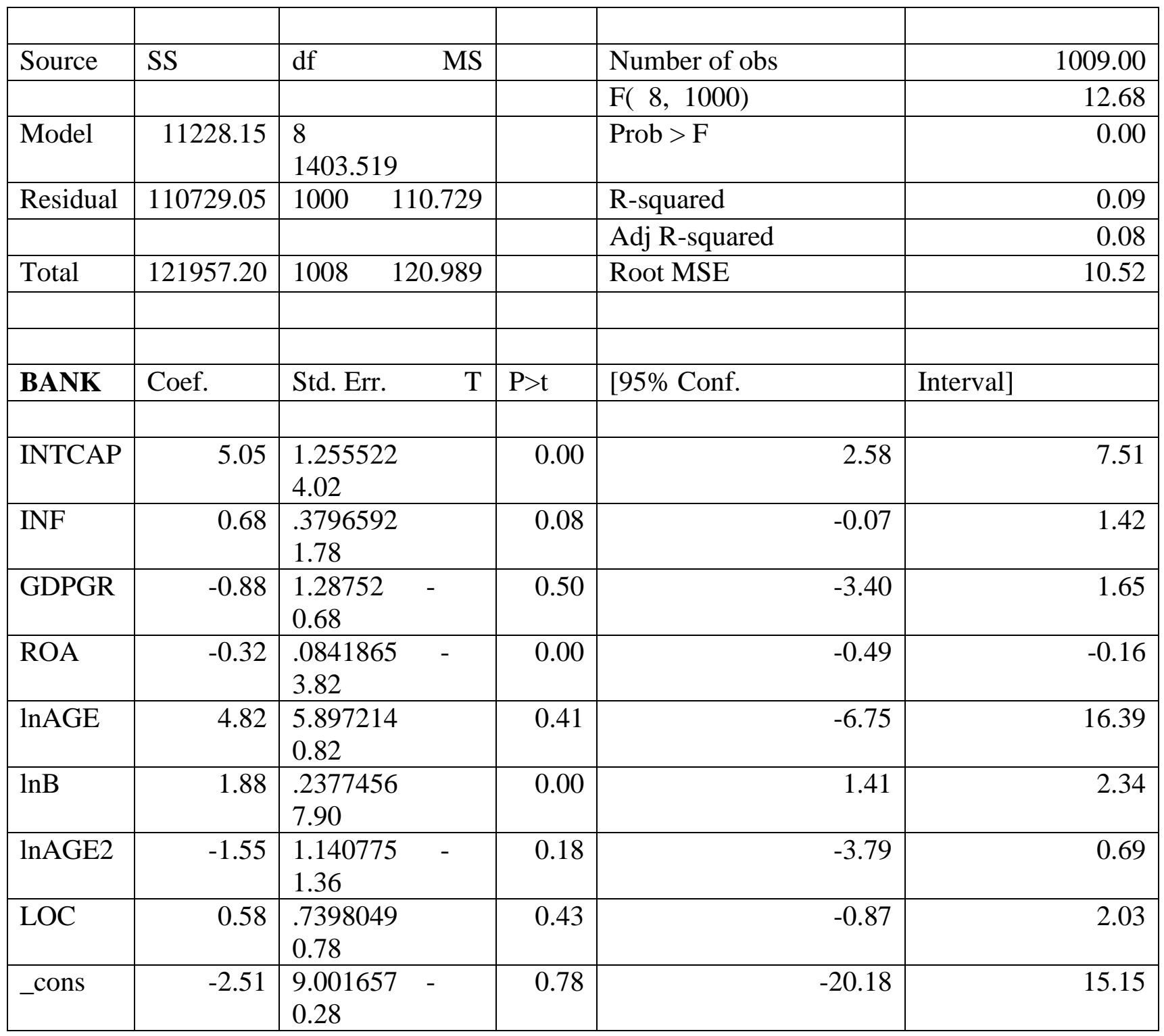

Table A3: OLS for model-3

\begin{tabular}{|l|l|l|l|l|r|}
\hline Source & SS & $\begin{array}{l}\text { df } \\
\text { MS }\end{array}$ & & Number of obs & 1009 \\
\hline & & & & F( 8, 1000) & 6.67 \\
\hline Model & 1132.734 & $\begin{array}{l}8 \\
141.591797\end{array}$ & & Prob > F & 0 \\
\hline Residual & 21227.89 & $\begin{array}{l}1000 \\
21.2278932\end{array}$ & & R-squared & 0.0507 \\
\hline & & & & Adj R-squared & 0.0431 \\
\hline
\end{tabular}




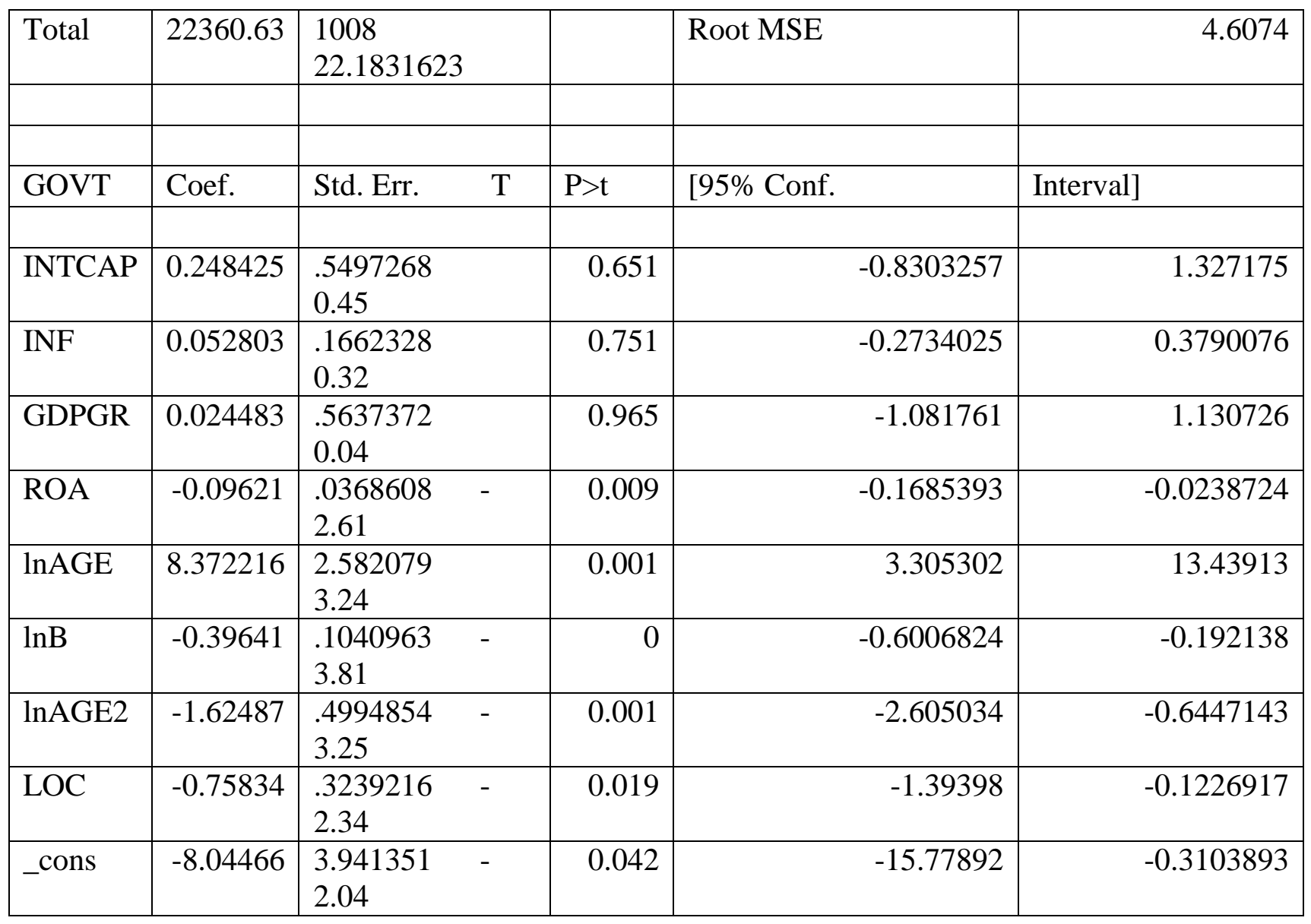

Table A4: OLS for model-4

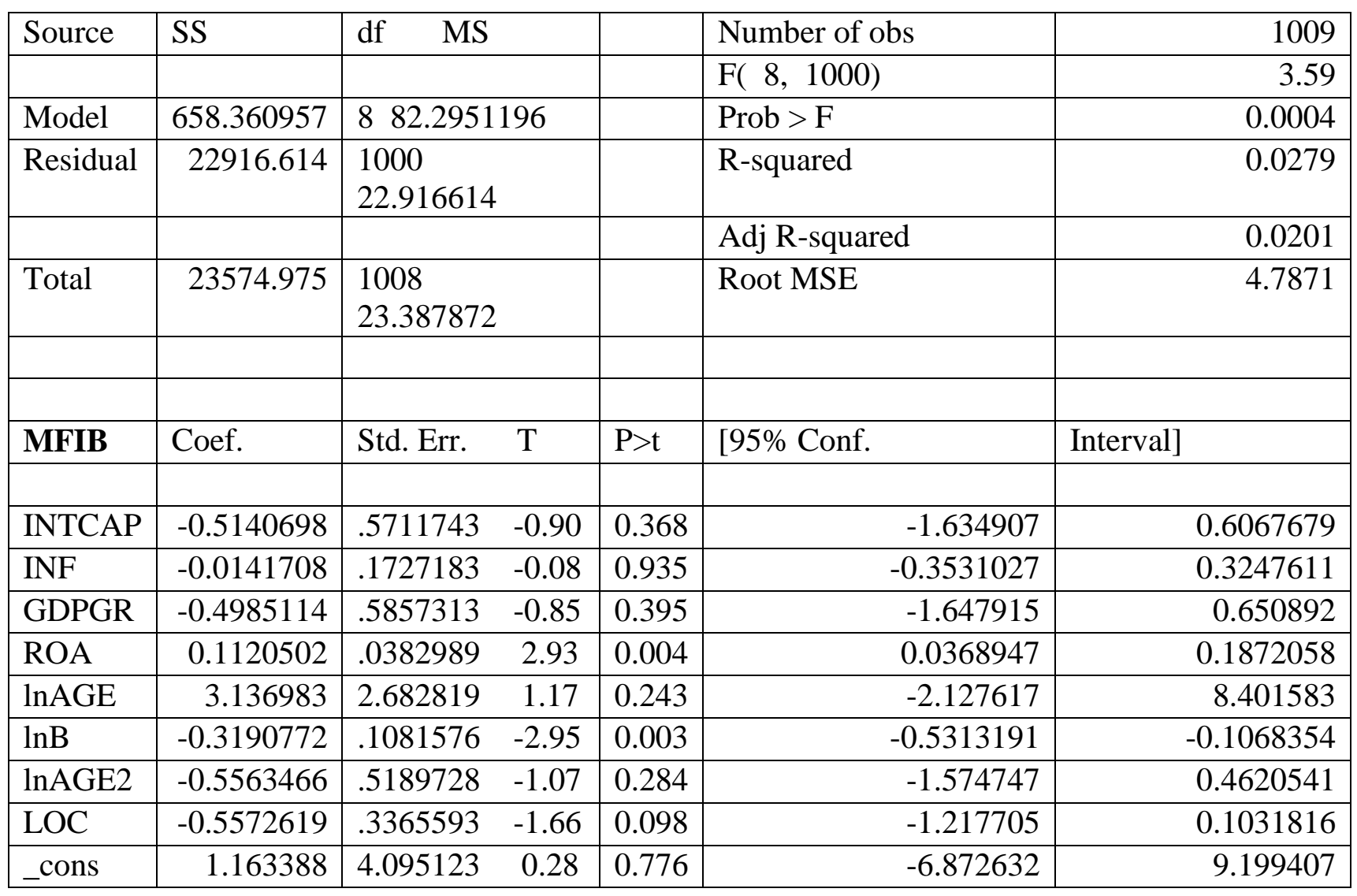


Table A5: OLS for model-5

\begin{tabular}{|c|c|c|c|c|c|}
\hline Source & SS & $\begin{array}{l}\mathrm{df} \\
\mathrm{MS}\end{array}$ & & $\begin{array}{l}\text { Number of } \\
\text { obs }\end{array}$ & 1009 \\
\hline & & & & $\begin{array}{l}\mathrm{F}(8, \\
1000)\end{array}$ & 25.21 \\
\hline Model & 129095.522 & 16136.9403 & & Prob $>F$ & 0 \\
\hline Residual & 640014.746 & $\begin{array}{l}1000 \\
640.014746\end{array}$ & & R-squared & 0.1679 \\
\hline & & & & $\begin{array}{l}\text { Adj R- } \\
\text { squared }\end{array}$ & 0.1612 \\
\hline Total & 769110.268 & $\begin{array}{l}1008 \\
763.006218\end{array}$ & & Root MSE & 25.299 \\
\hline PKSF & Coef. & Std. Err. $\quad \mathrm{t}$ & $\mathrm{P}>\mathrm{t}$ & [95\% Conf. & Interval] \\
\hline INTCAP & -8.59246 & $\begin{array}{ll}3.018481 & -2.85\end{array}$ & 0.005 & -14.51574 & -2.669177 \\
\hline INF & -1.298126 & $.9127632 \quad-1.42$ & 0.155 & -3.089277 & 0.4930252 \\
\hline GDPGR & 1.510438 & $3.09541 \quad 0.49$ & 0.626 & -4.563806 & 7.584683 \\
\hline ROA & -1.142845 & $.2023982-5.65$ & 0 & -1.540019 & -0.7456709 \\
\hline $\ln \mathrm{AGE}$ & 85.6115 & $14.17787 \quad 6.04$ & 0 & 57.78971 & 113.4333 \\
\hline $\ln B$ & 4.193141 & $.5715795 \quad 7.34$ & 0 & 3.071509 & 5.314774 \\
\hline $\ln \mathrm{AGE} 2$ & -14.32086 & $2.742612 \quad-5.22$ & 0 & -19.70279 & -8.938924 \\
\hline LOC & -1.032405 & $1.778613 \quad-0.58$ & 0.562 & -4.522647 & 2.457836 \\
\hline _cons & -101.4312 & $21.64147 \quad-4.69$ & 0 & -143.8991 & -58.9633 \\
\hline
\end{tabular}

Table A6: Robust Check for model 1

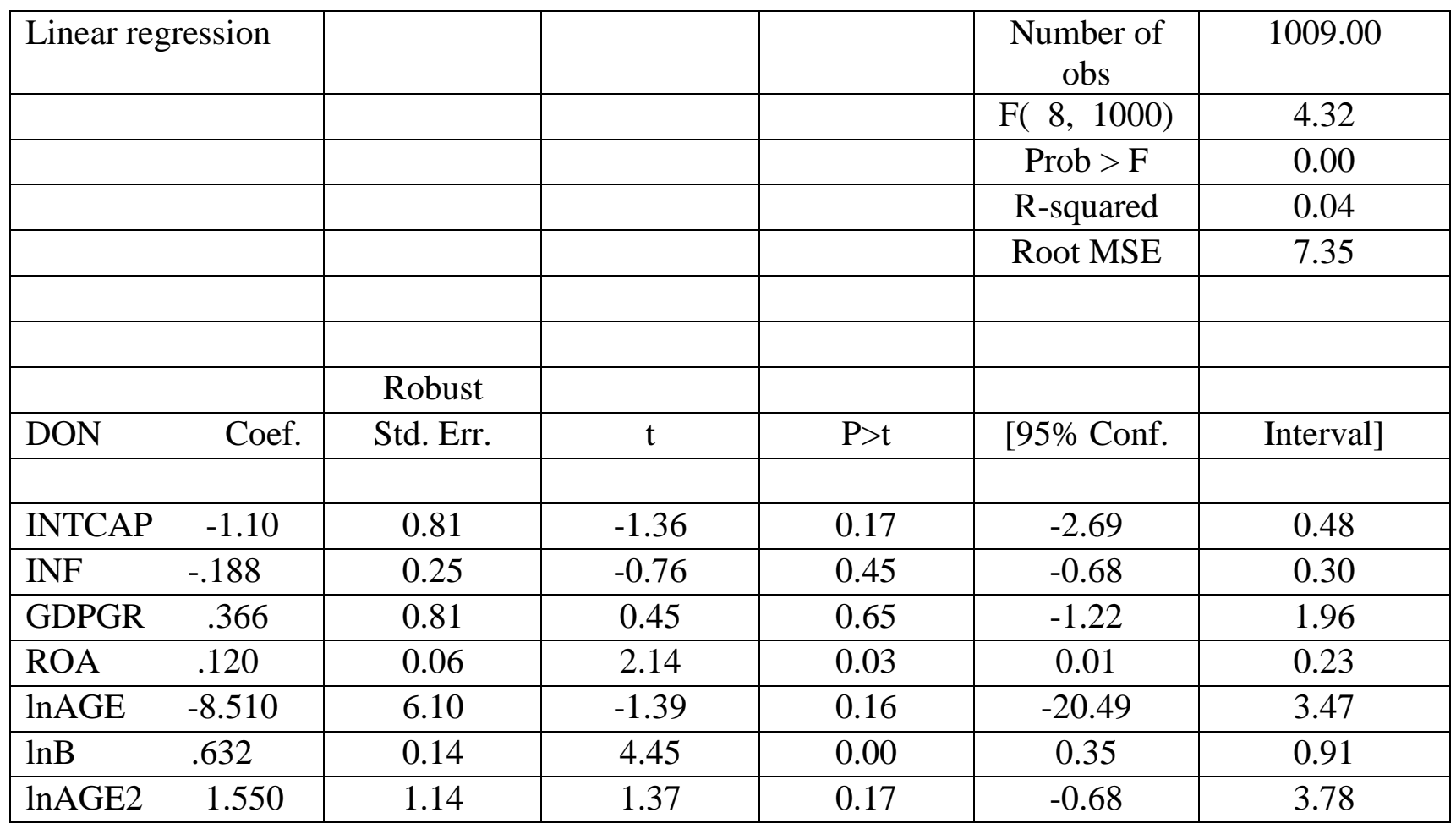




\begin{tabular}{|lc|c|c|c|c|c|}
\hline LOC & -.726 & 0.51 & -1.43 & 0.15 & -1.72 & 0.27 \\
\hline _cons & 11.566 & 8.51 & 1.36 & 0.17 & -5.13 & 28.26 \\
\hline
\end{tabular}

Table A7: Robust Check for model 2

\begin{tabular}{|c|c|c|c|c|}
\hline Linear regression & & & & Number of obs \\
\hline & & & & $\mathrm{F}(8,1000)$ \\
\hline & & & & Prob $>F$ \\
\hline & & & & R-squared \\
\hline & & & & Root MSE \\
\hline & & & & \\
\hline & Robust & & & \\
\hline BANK Coef. & Std. Err. & $\mathrm{t}$ & $\mathrm{P}>\mathrm{t}$ & [95\% Conf. \\
\hline $\begin{array}{l}\text { INTCAP } \\
5.046054\end{array}$ & 1.36 & 3.70 & 0.00 & 2.37 \\
\hline $\begin{array}{ll}\text { INF } & .677068 \\
\end{array}$ & 0.39 & 1.74 & 0.08 & -0.09 \\
\hline $\begin{array}{c}\text { GDPGR - } \\
.878072\end{array}$ & 1.34 & -0.65 & 0.51 & -3.51 \\
\hline ROA $\quad-.3211897$ & 0.09 & -3.54 & 0.00 & -0.50 \\
\hline $\begin{array}{c}\ln \mathrm{AGE} \\
4.817849 \\
\end{array}$ & 5.79 & 0.83 & 0.41 & -6.54 \\
\hline $\operatorname{lnB} \quad 1.877266$ & 0.31 & 6.01 & 0.00 & 1.26 \\
\hline $\begin{array}{c}\text { lnAGE2 - } \\
1.547518\end{array}$ & 1.08 & -1.43 & 0.15 & -3.67 \\
\hline LOC $\quad .5799564$ & 0.73 & 0.80 & 0.43 & -0.84 \\
\hline _cons $\quad-2.513548$ & 8.75 & -0.29 & 0.77 & -19.69 \\
\hline
\end{tabular}

Table A8: Robust Check for model 3

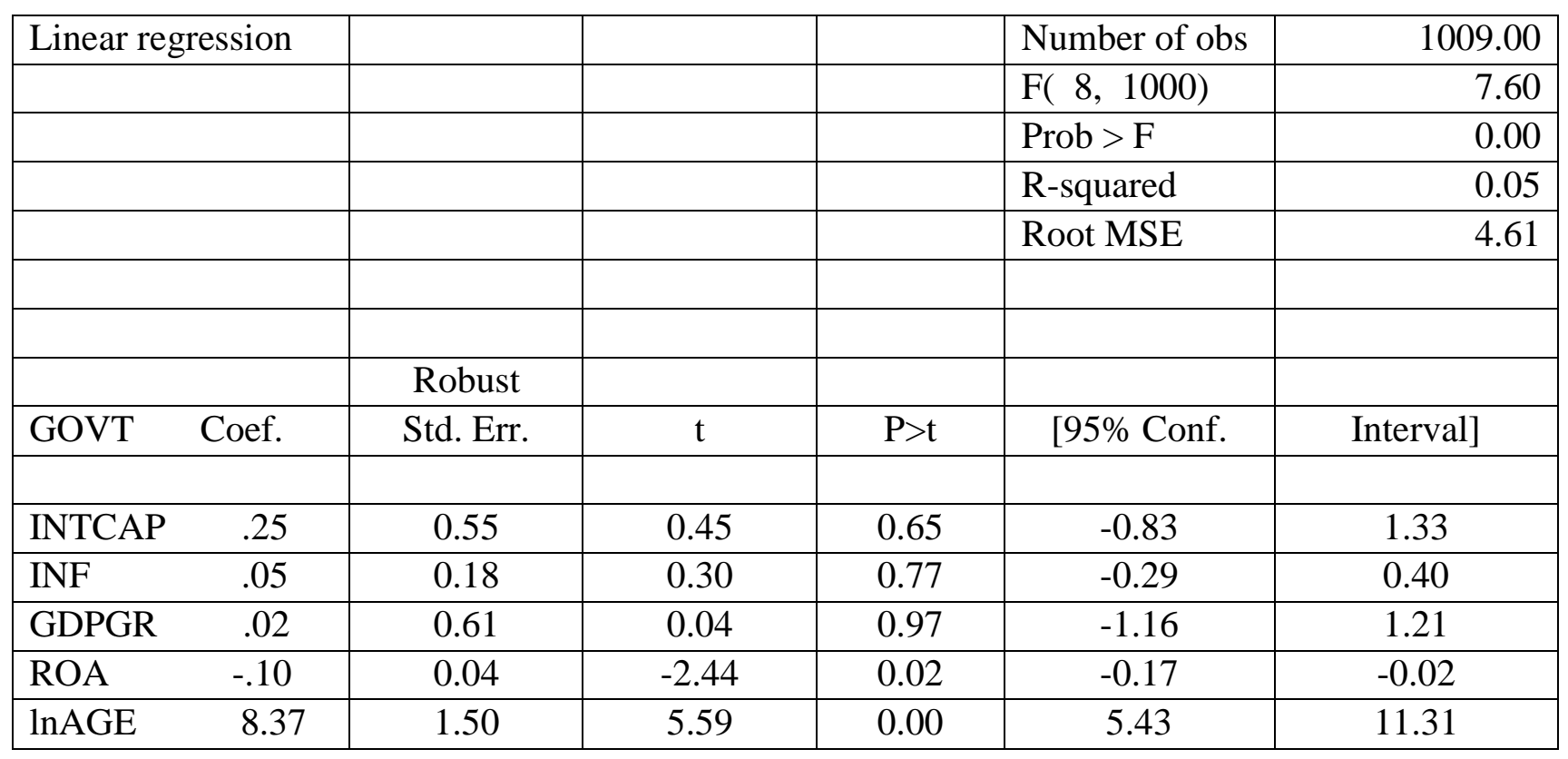




\begin{tabular}{|lc|l|l|l|l|l|}
\hline $\operatorname{lnB}$ & -.40 & 0.09 & -4.40 & 0.00 & -0.57 & -0.22 \\
\hline $\ln \mathrm{AGE} 2$ & -1.62 & 0.29 & -5.63 & 0.00 & -2.19 & -1.06 \\
\hline LOC & -.76 & 0.29 & -2.63 & 0.01 & -1.32 & -0.19 \\
\hline _cons & -8.04 & 2.76 & -2.92 & 0.00 & -13.45 & -2.64 \\
\hline & & & & & & \\
\hline & & & & & & \\
\hline
\end{tabular}

Table A9: Robust Check for model 4

\begin{tabular}{|c|c|c|c|c|c|}
\hline Linear regression & & & & Number of obs & 1009.00 \\
\hline & & & & $\mathrm{F}(8,1000)$ & 3.32 \\
\hline & & & & Prob $>\mathrm{F}$ & 0.00 \\
\hline & & & & R-squared & 0.03 \\
\hline & & & & Root MSE & 4.79 \\
\hline & & & & & \\
\hline & Robust & & & & \\
\hline MFIB Coef. & Std. Err. & $\mathrm{t}$ & $\mathrm{P}>\mathrm{t}$ & [95\% Conf. & Interval] \\
\hline $\begin{array}{l}\text { INTCAP - } \\
.5140698\end{array}$ & 0.52 & -0.98 & 0.33 & -1.54 & 0.52 \\
\hline $\begin{array}{l}\mathrm{INF} \\
.0141708\end{array}$ & 0.16 & -0.09 & 0.93 & -0.32 & 0.29 \\
\hline $\begin{array}{l}\text { GDPGR - } \\
.4985114\end{array}$ & 0.51 & -0.98 & 0.33 & -1.49 & 0.50 \\
\hline $\begin{array}{l}\text { ROA } \\
.1120502\end{array}$ & 0.05 & 2.27 & 0.02 & 0.02 & 0.21 \\
\hline $\begin{array}{l}\ln A G E \\
3.136983\end{array}$ & 2.18 & 1.44 & 0.15 & -1.13 & 7.41 \\
\hline $\begin{array}{l}\ln B \\
.3190772\end{array}$ & 0.08 & -4.03 & 0.00 & -0.47 & -0.16 \\
\hline $\begin{array}{l}\ln \mathrm{AGE} 2 \quad- \\
.5563466\end{array}$ & 0.41 & -1.35 & 0.18 & -1.36 & 0.25 \\
\hline $\begin{array}{l}\text { LOC } \\
.5572619\end{array}$ & 0.32 & -1.72 & 0.09 & -1.19 & 0.08 \\
\hline _cons 1.163388 & 3.67 & 0.32 & 0.75 & -6.03 & 8.36 \\
\hline
\end{tabular}

Table A10: Robust Check for model 5

\begin{tabular}{|c|l|l|l|c|c|}
\hline Linear regression & & & & Number of obs & 1009.00 \\
\hline & & & & $\mathrm{F}(8,1000)$ & 38.71 \\
\hline & & & & Prob $>\mathrm{F}$ & 0.00 \\
\hline & & & & R-squared & 0.17 \\
\hline & & & & Root MSE & 25.30 \\
\hline & & & & & \\
\hline & & & & & \\
\hline
\end{tabular}




\begin{tabular}{|c|c|c|c|c|c|}
\hline & Robust & & & & \\
\hline PKSF & Std. Err. & $\mathrm{t}$ & $\mathrm{P}>\mathrm{t}$ & [95\% Conf. & Interval] \\
\hline $\begin{array}{ll}\text { INTCAP } & - \\
8.59246 & \end{array}$ & 2.91 & -2.96 & 0.00 & -14.29 & -2.89 \\
\hline-1.298126 & 0.90 & -1.45 & 0.15 & -3.05 & 0.46 \\
\hline $\begin{array}{l}\text { GDPGR } \\
1.510438\end{array}$ & 3.00 & 0.50 & 0.62 & -4.37 & 7.39 \\
\hline $\begin{array}{l}\text { ROA } \\
1.142845\end{array}$ & 0.22 & -5.27 & 0.00 & -1.57 & -0.72 \\
\hline $\ln A G E \quad 85.6115$ & 12.90 & 6.64 & 0.00 & 60.30 & 110.92 \\
\hline 4.193141 & 0.59 & 7.08 & 0.00 & 3.03 & 5.36 \\
\hline $\begin{array}{l}\ln \text { AGE2 - } \\
14.32086\end{array}$ & 2.66 & -5.38 & 0.00 & -19.54 & -9.10 \\
\hline $\begin{array}{l}\text { LOC } \\
1.032405\end{array}$ & 1.78 & -0.58 & 0.56 & -4.52 & 2.46 \\
\hline _cons $\quad-101.4312$ & 18.92 & -5.36 & 0.00 & -138.56 & -64.30 \\
\hline
\end{tabular}

Table A11: Hausman Test

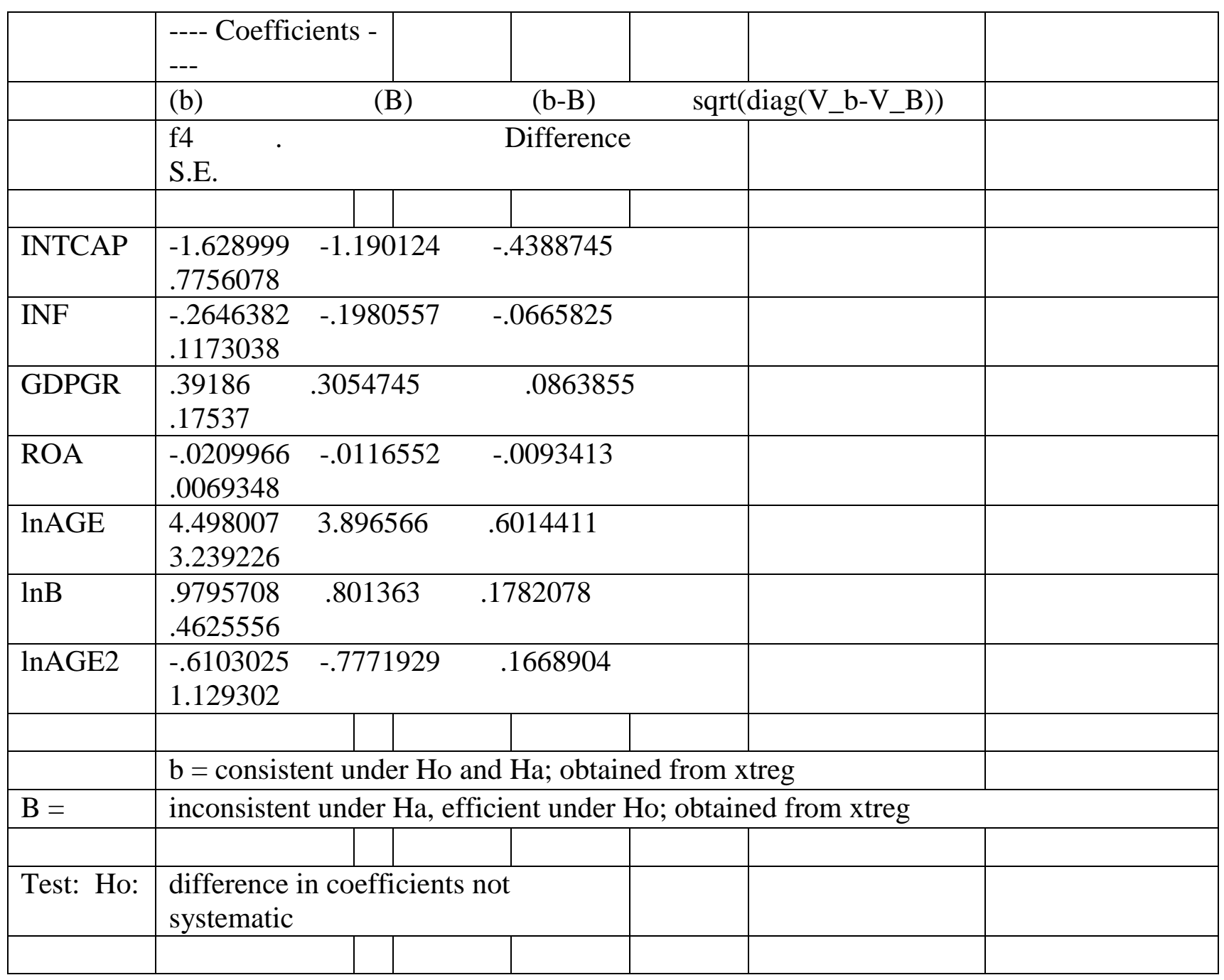




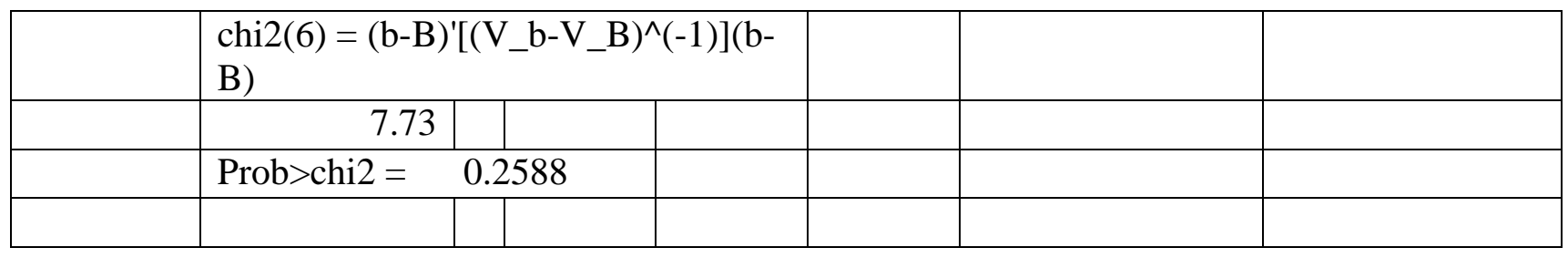

Table-A12: Fixed effect:

\begin{tabular}{|l|c|c|c|c|c|}
\hline & $(1)$ & $(2)$ & $(3)$ & $(4)$ & $(5)$ \\
\hline & DON & BANK & GOVT & MFIB & PKSF \\
\hline INTCAP & $-1.6290^{*}$ & -2.0512 & -0.4234 & 0.6151 & $-4.0123^{*}$ \\
& $(0.9187)$ & $(1.7358)$ & $(0.7673)$ & $(0.7368)$ & $(2.2764)$ \\
\hline INF & -0.2646 & -0.4422 & -0.0482 & 0.1510 & -0.5359 \\
& $(0.1736)$ & $(0.3281)$ & $(0.1450)$ & $(0.1393)$ & $(0.4302)$ \\
\hline GDPGR & 0.3919 & 0.8799 & 0.1172 & $-0.6760^{*}$ & 0.4054 \\
& $(0.4487)$ & $(0.8478)$ & $(0.3748)$ & $(0.3599)$ & $(1.1119)$ \\
\hline ROA & -0.0210 & $-0.1373^{* *}$ & 0.0276 & -0.0168 & $-0.2071^{* *}$ \\
& $(0.0365)$ & $(0.0690)$ & $(0.0305)$ & $(0.0293)$ & $(0.0905)$ \\
\hline LOC & 0.0000 & 0.0000 & 0.0000 & 0.0000 & 0.0000 \\
& $()$. & $()$. & $()$. & $()$. & $()$. \\
\hline lnAGE & 4.4980 & $-23.5443^{* * *}$ & $12.3888^{* * *}$ & 2.2543 & $47.9744^{* * *}$ \\
& $(4.9401)$ & $(9.3341)$ & $(4.1263)$ & $(3.9624)$ & $(12.2415)$ \\
\hline lnB & $0.9796^{*}$ & 0.9699 & 0.3492 & -0.5916 & 0.7988 \\
& $(0.5541)$ & $(1.0469)$ & $(0.4628)$ & $(0.4444)$ & $(1.3730)$ \\
\hline lnAGE2 & -0.6103 & $8.7801^{* * *}$ & $-2.0764^{*}$ & -1.0837 & $-9.9900^{* * *}$ \\
& $(1.3791)$ & $(2.6057)$ & $(1.1519)$ & $(1.1061)$ & $(3.4173)$ \\
\hline _cons & -7.1755 & -0.9695 & $-17.2991^{* * *}$ & $7.7038^{*}$ & $-29.1821^{* *}$ \\
& $(5.1103)$ & $(9.6557)$ & $(4.2685)$ & $(4.0989)$ & $(12.6633)$ \\
\hline$N$ & 1009 & 1009 & 1009 & 1009 & 1009 \\
\hline F & 3.2021 & 14.0527 & 3.2088 & 3.6415 & 12.2856 \\
\hline r2_a & -0.1784 & -0.0823 & -0.1783 & -0.1742 & -0.0968 \\
\hline N_g & 169.0000 & 169.0000 & 169.0000 & 169.0000 & 169.0000 \\
\hline Standard & para & & &
\end{tabular}

Standard errors in parentheses

${ }^{*} p<0.10,{ }^{* *} p<0.05,{ }^{* * *} p<0.01$

\section{Copyrights}

Copyright for this article is retained by the author(s), with first publication rights granted to the journal. This is an open-access article distributed under the terms and conditions of the Creative Commons Attribution license (http://creativecommons.org/licenses/by/4.0) 